(Originally published in The Journal of Psychology and Theology, 1982, Vol. 10, No. 3, 221-229. Copyright 1982 by Rosemead School of Psychology, Biola University)

\title{
THE GNOSTIC INFLUENCE ON PSYCHOLOGY: EFFECTS OF THE COMMON HERESY
}

\author{
BRUCE SCHWEIGERDT \\ California State University \\ Sacramento, California \\ Judeo-Christian theology has been plagued throughout its history by heresy \\ concerning, among many things, the doctrine of God and of human nature. \\ Psychology, possessing a generally fluid doctrine of human nature - from the \\ dualistic to the holistic, from the analytical to the existential, from the "dark \\ shadow" to the supreme good - has also been plagued by anthropological \\ heresy. This article tentatively suggests that historical psychology has built its \\ anthropology upon philosophical presuppositions in the tradition of the Gnostic \\ heresy.
}

"Whence evil, and why?" was, as Tertullian asserted, a burning question in all Gnostic movements, indeed, the real basis of their "heresy," which resulted from the fact that they meditated too long on it. (Schoeps, 1964/1969)

Gnosticism is a highly intellectual way of life and thought; therein lies its doctrine, its enticements, and its appeal. Historically it has been categorized as strictly a religious movement which flourished briefly in the second and third centuries A.D. only to die out as orthodox Christianity gained increased power and influence. However, as Doresse (1958/1960) suggests, with the universal curiosity of the eighteenth century - during which time "there were mystics, occultists and hermetists searching for spiritual food in all the most ancient and peculiar places - the Gnosticism of antiquity began to be thought less unworthy of interest" (p. 1).

The nature of this article is to address some of the relevant components of psychology, those which have integrated, to a significant degree, the basic concepts of Gnostic thought. The writing is by no means exhaustive of this subject but is a tentative attempt to outline the Gnostic influence. Therefore, the format of presentation follows the evolution of psychology from the "scientific," through the analytical and the humanistic modes, finally concluding in what I term "Fourth Force Psychology," the attempts to integrate Western psychology with Eastern mysticism.

\section{Origins of Gnosticism}

The term Gnosticism itself presents us with some difficulty. Yamauchi (1973) in trying to locate a pre-Christian existence of Gnosticism says,

On the one hand, we have those who would define Gnosticism very narrowly and, on the other hand, we have those who would define the phenomenon quite broadly.... Scholars who operate with a "broad" definition of Gnosticism find it not only in the New Testament but in many [pre-

Christian] documents as well. (p. 13)

For the sake of our discussion we will assume this broader perspective. Therefore, Gnosticism is herein defined as a pre-Christian religious (metaphysical and philosophical included) movement which, by name (Gnosticism) flourished during the early centuries of Christendom. It attempted to reconcile numerous, conflicting systems of belief, including Oriental (Persian, Egyptian, Indian) and Hellenistic (Stoic, Neoplatonic-Orphic-Pythagorean) elements. There are also components of apocalyptic or mystical Judaism found in its doctrines.

Gnosticism is derived from gnosis, the Greek word for "knowledge." In a religious sense the Gnostic claimed to have a unique and secret knowledge of God. But, mixed with this philosophic quest, the intellectual concept of rationalism was introduced; natural reason was the way to attain this higher knowledge.

On the one hand the "knowledge" implied here is a word specifically employed from the first dawn of religious inquiry to designate the science of things divine. And yet, in its own way, it meant a knowledge which brings healing, not of body but of soul. The Gnostic's life quest 
included an absolute disdain for things physical, combined with a strong fascination for things spiritual. It was the secret knowledge and ascetic life style which the Gnostic believed would heal the soul and bring salvation.

What then, fundamentally, is gnosis as experienced by the classic practitioner?

An experience or a theory which has reference to some definite interior mental happening, destined to become an inadmissible and inalienable state whereby in the course of an illumination, which is regeneration and divinization, man is re-established in himself, again remembers himself and becomes conscious of himself as an effluence from God and a stranger in the world. He thus acquires, with the possession of his "ego" and his true and ontological being, the meaning of his destiny and the final certainty of his salvation, thus discovering himself as a being who, by right and for all eternity, is saved (Puech, 1955. p 29)

\section{Motifs of Gnosticism}

Inherent in Hellenistic concepts is the quest for reason (as opposed to authority), a concept which is quite notable in the eighteenth, nineteenth, and twentieth centuries. The enthroning of reason as the highest part of the human personality, as opposed to faith, is not new to humankind; in essence, the Greeks started it. Such thinking led them, in a grossly idealistic way, into some of the most profound mythologies the world has known, mythologies believed in by the Greeks but rejected by the pre-eighteenth-century thinker in favor of modern science.

Integrated with a quest for reason, two basic assumptions concerning matter were made by the Gnostic. First, matter is basically evil and only spirit is good. Second, the Gnostic believed that matter is eternal; and that the universe was created out of this evil matter. Such assumptions present some tremendous theological problems in such areas as the doctrine of creation and the doctrine of the person of Jesus Christ, but it especially affects a person's view of life and the way life is lived. For since the body is matter, it therefore is evil. Based on this assumption, two possible courses can be followed: (a) Asceticism, where the body is punished by depriving it of all desires and even needs, or (b) complete licentiousness whereby all restraints on the physical are disregarded. For if the body is evil it hardly matters what a person does with it.

The Gnostic view of the Divine is that "he" is, indeed, supremely transcendent but also essentially unknown and, furthermore, unknowable. Because they viewed the world as bad, it could therefore not be redeemed. Only the divine spark, which somehow is imprisoned in some humans, is capable of salvation. "[The divine spark] is saved when, by divine grace, it comes to know itself, its origin, and its destiny" (Grant, 1961, p. 15).

\section{Gnostic Dualism}

Perhaps the cardinal feature of Gnostic thought is the radical dualism that governs the relation of God and world, and correspondingly that of humanity and world. This is a dualism of realms of being - God and the world, spirit and matter, soul and body, light and darkness, good and evil, life and death - and consequently an extreme polarization of existence, affecting not only humanity but reality as a whole. The general religion of the Gnostic period is a dualistic, transcendent religion of salvation (Jonas, 1958, pp. 42, 31).

Gnosticism, as Mead suggests, represents a "funnel" through which cultures were "strained"; that is, the East into the West. The Greek culture desperately clung to a new found concept, "science," but through its quest for philosophy, it needed a science that could answer its ultimate questions. Gnostic philosophy here provided for a science of the soul, the most abstract element of human experience. This science of the soul was a new knowledge of things unseen.

The seeds were established and the crop was growing when Descartes (1948) in 1637 laid the material for one of the most basic of psychological concepts by declaring that "I am...lodged in my body as a pilot in a vessel" (p. 94). From that point mind was seen as a distinct entity, existing independently of the body, although closely conjoined to it (Myers, 1978, p. 63).

Such a doctrine invites a mind-over-matter logic which is reminiscent of Eastern religion, prevalent in Hinduistic and Buddhistic thought. King (1864/1973), asserting his Indian origin for Gnosticism, says:

Certain Gnostic tenets concerning the duality of the Divine emanations, absorption into the godhead, asceticism, penance, and self-collection, are identical with the Buddhistic teaching upon the same points. (p. 42) 
Schmithals (197I) also traces the origins of dualism but does not go as far as King in his conclusions:

The body as prison of the soul has as its presupposition the anthropological dualism of Hellenism and the cosmological dualism of the religion of Zarathustra. Thus Gnosticism as an understanding of human existence is older than the religio-historical phenomenon of "Gnosticism"... [This concept], by which man is pulled in both ways... in such a fashion that he himself is seen dualistically, is hardly to be explained without reference to the religious and philosophical traditions of Greece (that stream of Greek dualism as it confronts us in Plato's Phaedo as the earliest explicit source).... The decisive turn to Gnosticism lay in the fact that man recognized his real self, his soul, as a part of the god "Man." (pp 26-33)

In essence what Gnostic dualism did is to merge a new understanding of God, humanity, and the world. It was a view that was to stay with the Western world for millennia of time. For in the West we have traditionally based our thinking (scientific, philosophic religious) on dualistic and trichotomistic theories and as a result a holistic view of human nature seems totally foreign to us.

\section{Gnosticism as Science}

Much of modern psychology uses as its basic motif a scientific objectivity. In other words, a science of the mind (soul-psyche) was used as the legitimate entry into the intellectual circles of the modern age.

"Science" is as old as the ancient creeds and myths of astrology wherein persons were thought to be subject to the planets and constellations from before birth until death. Western science is derived from the Greeks with their refined mathematics, medicine, and astronomy. Van Groningen (1967) theorizes that Gnosticism is a discipline of science:

In my study of various works of scholars dealing with Gnosticism, I became aware of the fact that most of them ignored the scientific aspects of Hellenic culture. [An] aspect of my thesis is that all men are by nature inclined to partake in the spirit of scientism. Hellenism, because of its strong scientific elements, therefore gave stimulation to this inherent characteristic and/or trait of man. (p. 38)

Gnosis, according to Van Groningen, is the individual's attempt "to know and control his existence and free it from slavery. This is basically a scientific spirit. Gnostics sought a scientific approach and method to gain their freedom. Thus Gnosticism at heart and in spirit should be seen as an expression of scientism which became a religious force in the lives of many" (p. 49).

\section{Gnosticism and Psychoanalysis}

There are several elements of Freudian and Jungian psychoanalysis that suggest Gnostic influence. Freud and Jung, both medical doctors, considered themselves scientists; in reality, their primary interests in life were philosophic. Their theories represent a major transition from the "science" of psychology to the "art" of psychology. They were classical mind therapists whose art was healing - the healing of the soul. It is quite possible that our current use of the word therapist originates with the first century Jewish Essene sect of Therapeutaes, those "wisdomlovers" who professed an art of healing superior to that of the body, in fact, a healing of the soul. Mead (c.1900/1960, p. 66) suggests such a connection, but a further statement which Mead makes in this regard as he describes the daily routine of these therapeuts has profound implications for our discussion on psychoanalysis:

The whole interval from dawn to sunset they devote to their exercises. Taking the sacred writings they spend their time in study [literally, philosophie), interpreting their ancestral code allegorically, for they think that the words of the literal meaning are symbols of a hidden nature which is made plain [only] by the under-meaning. (pp. 70-71)

Horney (1950), in her discussion of the origins of psychoanalysis delineates the antiquity of this therapeutic mode:

The road of analytic therapy is an old one, advocated time and again throughout human history. In the terms of Socrates and the Hindu philosophy, among others, it is the road to reorientation through self-knowledge. What is new and specific about it is the method of gaining self-knowledge, which we owe to the genius of Freud. ( $p 341$ ) 


\title{
Freudian Psychoanalysis
}

But is the classic neo-analytical approach really any different from the philosophies of the ancient self-seekers? The philosophic presupposition of Freudian psychoanalysis is based on the ancient "nature philosophy" that was so popular during the past century. Jones (1953), Freud's friend and biographer, who agrees with this premise, sets the cultural stage for us:

\begin{abstract}
Naturephilosophie is the name of the pantheistic monism, close to mysticism, which, professed by Schelling - repeated, developed, and varied by a host of writers - was eagerly accepted by the average educated man and liberated lady. The Universe, Nature, is one vast organism, ultimately consisting of forces, of activities, of creations, of emergings - organized in eternal basic conflicts, in polarity; reason, conscious life, mind being only the reflection, the emanation, of this unconscious turmoil. These ideas have been expressed before and since and contain the seed of some of the scientific theories of the nineteenth century and of our time....the aspiration expressed in the name "speculative physics" (which Schelling himself gave to his endeavors). ( $p$ 43)
\end{abstract}

This was the tenor of the times and Freud was a product of these times. Freud, in his reading, was heavily influenced by Goethe who wrote much of good versus evil, God versus the devil, but from a strictly pantheistic viewpoint:

The Theories of Darwin, which were then of topical interest [1870s], strongly attracted me, for they held out hopes of an extraordinary advance in our understanding of the world; and it was hearing Goethe's beautiful essay on Nature read aloud at a popular lecture by Professor Carl Bruhl just before I left school that decided me to become a medical student. (cited in Jones, 1953, p 28)

Bakan (1958) deals with the struggle this produced in Freud's thought and methodology when he based his life on this pantheistic philosophy made so popular by Goethe. Freud desired, first and foremost to "heal" his patients of guilt, the classical soul problem:

[In Freud's mind] the disease of the neurotic is his guilt. This guilt is, in itself, an evil and its removal is good. However, within the neurosis the guilt is a punishment for evil. Within the neurosis a counter-force to the punishing imago is required. Hence there is an alliance with such a counter-imago as will allow all to become open, accessible to consciousness. If God is the guilt producing imago, then the Devil is the counterforce. As Freud said in discussing Anatole France's Revolt of the Angels, "War will produce war and victory defeat. God defeated becomes Satan and Satan victorious will become God." (pp. 232-233)

This allegorical paradox (the devil as good) was not a Freudian discovery but is clearly a synthesized Gnostic heresy. Historically the devil is associated with knowing, but his is a knowledge which is unable to scale the heights of wisdom (true insight). In the deed of eating from the Tree of Knowledge "the eyes of them were opened," they gained the knowledge of good and evil but sacrificed their natural ability to gain insight. "Seeing in," finding that self within, has been the epistomological quest of humanity since the dawn of history. Such a desire was the germ of Gnostic thinking and is the absolute desire and quest of the psychoanalyst. Through free association and dream interpretation, the classical analyst searches the forbidden reaches of the unknown trying to discover the knowable, continuing the missions of a Daniel or Joseph, however, without the prerequisite of divine assistance. Such an undertaking can lead to foreboding consequences for all humanity. Friedell (1933), a master of modern cultural historiography and a Viennese contemporary of Freud, suggests the diabolical pseudo-religiosity of psychoanalysis, a religiosity which Szasz (1976) calls a form of Jewish Gnosticism:

Psycho-analysis is in truth a sect, with all the signs and symbols of one - rites and ceremonies, oracles and mantic, settled symbolism and dogmatism, secret doctrine and popular edition, proselytes and renegades, priests who are subjected to tests, and daughter sects which damn each other in turn. Just as the whale, though a mammal, poses as a fish, so psychoanalysis, actually a religion, poses as a science. This religion is pagan in character: it embraces natureworship, demonology, chthonian belief in the depths, Dionysiac sex-idolization .... We have here a seer and singer working for the powers or darkness in most enticing tones, an Orpheus from the Underworld: it is a new world-wide revolt against the Gospel. (Friedell, 1933, p. 480)

\section{Jungian Psychoanalysis}

The branch of psychoanalysis founded by Freud's student, Carl Jung, represents an entirely different form of Gnostic integration into psychology. Jung, not Jewish but instead Protestant in background, actually preferred Gnosticism to orthodox Christianity because of its natural realities 
(Van Gronigen, 1967, p. 187). Jung made no secret of his fascination with occultism and often chided Freud for not realizing that his own theories had similar origins to Jung's. Mead (c. $1900 / 1960$ ) asserts that "for better or worse, the Gnostics were the founders of what we call occultism" (p. xv).

The bizarre in Jung's doctrine is overlooked by most authors who work from a Jungian viewpoint. However Fodor (1971, p. 22) has ably dealt with this subject. He suggests that Jung was subject to a five-year period of psychosis during which he developed a complementary position with Gnostic heresy and, through dream interpretation, communed with the devil himself. Jung delved in the world of cosmic consciousness and from this viewpoint he did his research and lived his life. De Young (1976) defines Jung's theory in this way: "Each man is himself and the whole human race. Life is a journey into Self - the Creative Self that integrates the polarities of existence" (p. 90). In the field of analytical psychology, Jung is seen as the link between depth psychology and the theories of nuclear physics:

Jung's research [gave] him the understanding that a certain unrecognizable reality exists beyond the world of psyche; such reality, in his view appears to exist beyond the causal manifestations of time and space, where the law of causality comes to an end, and where time and space are themselves relative. (Fodor, 1971, p. 192)

In Jung's concept of the archetype (a term he gained from Goethe's Urbild) he locates the collective unconscious. These eternally inherited and cyclically generated archetypes are complexes of experience that come upon us fatefully. As each person is in a search for a soul, salvation occurs through the realization that individuation is only important insofar as it effects the collective psyche. Such ideas have opened wide the door of mystical thinking as it impacts the field of psychology.

Freud and Jung, after their split, were in perpetual enmity with each other though they had no contact. There is little question that their theories and methodologies are different, but their origins are the same.

\section{Gnosticism and Humanistic Psychology}

In humanistic psychology we have "selfist theory" exemplified. There is certainly much to suggest a Gnostic influence here, but humanistic psychology only represents a transition between the reserved and restricted analytical movement and the "anything goes" ideas of "Fourth Force Psychology." Accordingly, this article deals briefly with humanistic psychology with the intent of demonstrating its role as the "funnel agent" in psychology.

Schmithals (1971) says that "the decisive turn to Gnosticism lay in the fact that man recognized his real self, his soul, as a part of the god 'Man'” (p. 33). Vitz (1977) brings this thought to modern times by referring to the 1854 work of Ludwig Feuerbach which he terms "the most important direct source for today's humanistic selfism" (p. 67). Vitz then cites the relevant parts of Feuerbach's work entitled, strangely enough, The Essence of Christianity:

The historical progress of religion consists in this: That which during an earlier stage of religion was regarded as something objective is now recognized as something subjective, so that which was formerly viewed and worshipped as God is now recognized as something human. But that which in religion ranks first - namely, God — is, as I have shown, in truth and reality something second; for God is merely the projected essence of Man.... What, therefore, ranks second in religion namely, Man - that must be proclaimed the first and recognized as the first.

If the nature of Man is man's Highest Being, if to be human is his highest existence, then man's love for Man must in practice become the first and highest law. Homo homini Deus est — man's God is MAN. This is the highest law of ethics. THIS IS THE TURNING POINT OF WORLD HISTORY. (Vitz, p. 68)

The humanistic perspective described here is basically an outgrowth of Gnostic dualism whereby human nature is nothing more nor less than a distant emanation of the divine essence (personal or impersonal) and salvation is found in progressing back to the beginning of this essence. The main difference, however, is that in the modern system of humanism there is no work, no selfdenial involved.

Vitz indicates that two tracks of modern psychology emerged from Feuerbach. The first to take hold grew out of the Continental School - Marx, Nietzsche, and Freud - and was brought to the 1950s and 1960s by Fromm and May. The second school (English) was promulgated by 
Mill, Huxley, and Dewey and popularized for psychology in the 1950s and 1960s by Rogers and Maslow. It is interesting in light of Feuerbach's definition to see how Transactional Analysis promoter Thomas Harris (1967/1973) fits into this schema; indeed Harris has synthesized both schools:

I would like to suggest that a reasonable approximation of this objective moral order, or of ultimate truth is that persons are important in that they are all bound together in a universal relatedness which transcends their own personal existence. Is this a reasonable postulate? The most helpful analytic concept in attempting to answer this question is the concept of comparative difficulties. It is difficult to believe that persons are important, and it is also difficult to believe they are not.... We cannot prove they are important. We have only the faith to believe they are, because of the greater difficulty of believing they are not. (p. 254)

On the surface such a statement on the value of humans suggests a high level of morality. In reality, it lacks all virtue since there is no longer any external "measuring stick," no objective law which determines such absolute definitions. All of history recounts what happens to persons when subjective feelings are used as the "final solution" in defining the worth of individuals. Adoration degenerates to mere respect and finally to contempt with its logical and awful consequences. Jonas (1958) lays the blame for such anthropological degeneracy at the feet of Gnostic teaching:

Among the reproaches which Plotinus raises against the Gnostics... is that they lack a theory of virtue; and he maintains that it is their contempt of the world that prevents them from having one.... Their doctrine... holds in contempt all the laws down here and virtue which has risen among men from the beginning of time, and puts temperance to ridicule. (p. 266)

At its worst, humanism is seen as human nature possessing a core of evil; at its best, humanism can only generate a pseudo-value system since the formulation of values is simply a subjective experience with some sort of governmental entity as the final social arbitrator. But when these forms of governance arbitrate, it tends to bring out this inherently evil human core rather than the hoped for idealistic peace so sought after by the humanist. The end result of this is a subjective subjectivity, a sort of sophisticated solipsism or, more classically, an existential view of reality.

The existential, nihilistic, humanistic world-view then brings us to the door of Fourth Force Psychology. For the mystical religions of the East claim to hold an answer for the ultimate humanistic dilemma.

\section{Gnosticism and Fourth Force Psychology}

Thus far the historical influence of Gnostic thought upon various psychological systems has been addressed. But, should the current trends continue, what does the future hold for these secular psychological modes? Evolving from Gnostic concepts to an existential world view has done nothing to solve the human dilemma. There is a seeming difference between the two but an unwholesome sameness remains:

There is no overlooking one cardinal difference between the gnostic and the existentialist dualism. Gnostic man is thrown into an antagonistic, anti-divine, and therefore anti-human nature; modern man into an indifferent one. Only the latter case represents the absolute vacuum, the really bottomless pit (Jonas, 1958, p. 338)

Humanism represents a temporary struggle out of this pit in an effort to fill the vacuum, but its final destiny is the same. In turn it was the Human Potential Movement which provided the bridge that was needed if psychology was again going to be reunited with its sibling, philosophy, through their common parent, religion:

The roots of the Human Potential Movement are in the scientific study of groups, the small group movement, sensitivity training, group therapy, sensory awareness, increasing Western awareness of certain Eastern religions, and in humanistic psychology. (Jud \& Jud, 1972, p. 13)

The religions of the West are not sufficiently esoteric to be included in a "science" of psychology, a concept which must be maintained for psychology to remain credible in this culture. Thus a "fourth force" in psychology has emerged to provide this "science of the soul" with a tie to the religions of the East. Note how the various Eastern religions of today try to pass themselves off as scientific (Yoga, faddish Transcendental Meditation, and Zen Buddhism) in the same way that 
the Gnostics who were quasi-scientific for their age tried to be identified as religious. Those who are encouraging this merging of science and religion describe the trend in this way:

An integration of science and eastern religion is clearly emerging. If science and religion are so broadly similar, and not arbitrarily limited in their domains, they should at sometime clearly converge. I believe this confluence is inevitable. For they both represent man's efforts to understand his universe and must ultimately be dealing with the same substance. As we understand more in each realm, the two must grow together... But converge they must, and through this should come new strength for both. (Townes, 1976, pp. 10-19)

The Gnostic influence here is unmistakable. The password used to gain entrance into our sophisticated scientific age by those wearing the cloak of religion is quantum physics. Emerging from this is a new psychology, Fourth Force Psychology, which is represented as a "science of consciousness" (Pelletier, 1978, pp. 32-66). This is exactly what the ancients experienced as metaphysics (Aristotle) or speculative physics, the same concept that was used in the earlier discussion of nature philosophy.

Therefore psychology has come full circle from speculative religion (the Eastern mysteries) through speculative philosophy (the Greeks), speculative science (the Gnostics), speculations concerning human nature (dualism), speculative philosophy again (Freudian and Jungian psychoanalysis), speculative human nature again (humanistic psychology), speculative science again (quantum physics), and finally to speculative religion (the Eastern mysteries).

The underlying problem to this circular dilemma is how humanity has handled the Gospel. This was the problem of the Gnostics in specific and humankind as a whole both before Christ and after. When the Resurrection is considered the central theme in Christian doctrine (I Corinthians 15) the distinction is clear between what Christ taught and experienced and what the Gnostics, Eastern mystics, and modern metaphysicists speculate. It is the case of the Resurrection versus a belief in reincarnation.

Reincarnation is implied in Gnosticism and certainly represents the basis of Eastern religions. Life becomes extremely insignificant to the Gnostic and the Eastern mystic, but to the Christian life is the basis of resurrection. Life is real and the world is real. We begin at conception but we die in the end, at death. It is only the Resurrection of Christ that gives life. All is not an illusion; we are not an emanation; we do not reincarnate or transmigrate. Life is important and, indeed, it is all that we have.

\section{Conclusion}

This article has attempted to demonstrate the strong influence that Gnostic thought has on present day psychology. Gnosticism has been defined as a syncretistic system that combined the esoteric religions of the East with the logic of the West. As a metaphysical science, it masqueraded as a religion. Its basic motif was that of a cosmological and anthropological dualism which made of the practitioner either a fanatical ascetic or a licentious pervert.

Psychology, trying to maintain a somewhat tenuous scientific image, has gone through at least five phases in its history as a discipline. The first of these is as a science of the soul (philosophical psychology). Next is the science of the metaphoric abstract in psychoanalysis. Thirdly, we have the science of humanism, so defined because of its cultural environs. Next is the "new found" science of consciousness, or quantum physics. And the latest and logical outgrowth of this evolution is the absolute science of religion, the systems of the East.

The main reason for such a progression is the radical way in which the Gnostics synthesized humanity's view of nature, what is termed today "nature philosophy." The Gnostic view that matter is evil is not biblical, nor is the view that human nature is simply an outgrowth of nature. For such views allow the Gnostic god to become the same as nature is in the East: Humanity is a part of God. With this monistic and pantheistic world-view all is one and one is all. And, in the end, all is nothing as in the beginning nothing is all.

Such thinking used to be completely foreign to the Western form of logic. But to an alarming degree, these ideas are becoming accepted dogma, and psychology, as a discipline, is seen as leading the way. 


\section{REFERENCES}

Bakan, D. Sigmund Freud and the Jewish mystical tradition. Princeton, NJ: Van Nostrand, 1958.

Decartes, R. The meditation and selections from the principles of Rene Descartes. La Salle, IL: Open Court. 1948.

DeYoung, Q.R. An unknown god made known (the religion of psychology). Journal of Psychology and Theology. 1976, 2. 87-93.

Doresse, J. [The secret books of the Egyptian Gnostics.] (P. Mairet, Trans.). New Your: Viking, 1960. (Originally published, 1958.)

Feverbach, L. [The essence of Christianity] (G. Eliot, Trans.). New York: Harper and Brothers, 1957. (Originally published 1854 .)

Fodor, N. Freud, Jung and ocultism. New York: University. 1971.

Friedell, E. [A cultural history of the modern age. The crisis of the European soul from the black death to the world war (Vol. 3)] (C.F. Atkinson, Trans.). New York: Knopf, 1933. (Originally published, 1932.)

Grant, R.M. Gnosticism: A source book of heretical writings from the early Christian period. New York: Harper and Brothers. 1961.

Harris, T.A. I'm OK - You're OK. New York: Avon, 1973. (Originally published, 1967.)

Horney, K. Neurosis and human growth. New York: Norton, 1950.

Jonas, $\mathrm{H}$. The Gnostic religion: The message of the alien god and the beginnings of Christianity. Boston: Beacon, 1958.

Jones, E. The life of Sigmund Freud (Vol. 1). New York: Basic, 1953.

Jud, G.J., \& Jud, E. Training in the art of loving: The church and the human potential movement. Philadelphia: Pilgrim, 1972.

King, C.W. The Gnostics and their remains, ancient and medieval. Savage, MN: Wizards Bookshelf, 1973. (Originally published, 1864.)

Mead, G.R.S. The Gnostics: Fragments of a faith forgotten. New York: University, 1960. (Originally published, 1900.)

Myers, D.G. The human puzzle: Psychological research and Christian belief. San Francisco: Harper/CAPS, 1978.

Pelletier, K.R. Toward a science of consciousness. New Your: Dell, 1978.

Puech, H.C., Quispel, G., \& Van Unnik, W.C. [The Jung codex: A newly recovered Gnostic papyrus.] (F.L. Cross, Trans.). London: Mowbray, 1955.

Schoeps, H.J. [Jewish Christianity: Factional disputes in the early church.] (D.R.A. Hare, Trans.). Philadelphia: Fortress, 1969. (Originally published, 1964.)

Schmithals, W. [Gnosticism in Corinth: An investigation of the letters to the Corinthians.] (J.E. Steely, Trans.). Nashville: Abingdon, 1971.

Szasz, T. Karl Kraus and the soul-doctors. Baton Rouge: Louisiana State University, 1976.

Townes, C. The convergence of science and religion. California Monthly, February, 1976, pp. 10-19.

Van Groningen, G. First century Gnosticism: Its origins and motif. Netherlands: E.J. Brill, 1967.

Vitz, P.C. Psychology as religion: The cult of self-worship. Grand Rapids: Eerdmans, 1977.

Yamauchi, E.M. Pre-Christian Gnosticism: A survey of the proposed evidences. Grand Rapids: Eerdmans, 1973.

\section{AUTHOR}

SCHWEIGERDT, BRUCE Title: Director, Family Guidance Center. Degrees: M.P.A., M.A., California State University, Sacramento. Specialization: Social work and marriage-family counseling. 